\title{
Study of the Mechanical Behavior of Agbelouve Silty Sand Stabilized with Cement Used as a Roadway Layer in Southern Togo
}

\author{
Abalo P'kla, Yawovi Mawuénya Xolali Dany Ayité* \\ Civil Engineering Department, Higher National School of Engineers, University of Lome, Lome, Togo \\ Email address: \\ jeanpierrepkla@gmail.com (A. P’kla),danyayite@gmail.com (Y. M. X. D. Ayité) \\ ${ }^{*}$ Corresponding author
}

To cite this article:

Abalo P'kla, Yawovi Mawuénya Xolali Dany Ayité. Study of the Mechanical Behavior of Agbelouve Silty Sand Stabilized with Cement Used as a Roadway Layer in Southern Togo. Advances in Materials. Vol. 8, No. 3, 2019, pp. 127-131. doi: 10.11648/j.am.20190803.15

Received: August 17, 2019; Accepted: September 5, 2019; Published: September 19, 2019

\begin{abstract}
Silty or slimy sand stabilized with cement is used as a base or foundation layer when good quality natural materials are not available nearby. However, its mechanical characteristics are far from being mastered. In this paper, mechanical characteristics at different ages of silty sand stabilized with cement at different rates are studied. For this, specimen of silty sand stabilized with cement at rates of $2.5,3.5$ and $4.5 \%$ are subjected to the Modified Proctor test and to the compressive and tensile strength tests at 7, 28, 60, 90 and 360 days of age. The results show that compressive and tensile strengths increase with age and cement rate. The study of the different correlations between the resistances allowed the theoretical estimation of the parameters of roadway dimensioning in particular the fatigue resistance under a million loading cycles and the design fatigue resistance.
\end{abstract}

Keywords: Silty Sand, Tensile Strength, Fatigue Resistance Under a Million Loading Cycles, Design Fatigue Resistance

\section{Introduction}

Road geotechnics uses soil stabilization with hydraulic binders (lime, cement) at low levels (usually between 2 and $5 \%$ or even $6 \%[10-14]$ ) to increase the physical and mechanical performance of a layer of form or roadway structure when there is presence of lower quality materials The silty or slimy sand stabilized with cement and used in foundation layer generally allows, according to the level of traffic and the class of the ground support, to guarantee a rather durable road. Its use, although common in the regions of the Togolese and Beninese littoral, is made without real knowledge of the mechanical characteristics in the medium and long term. Only the results at 7 days and sometimes at 28 days are presented during the study phase and project realization. This situation does not allow the knowledge of the parameters to be used in roadway design by the rational method [10] which require at least the static characteristics at 360 days of the stabilized material in the absence of cyclic loading tests for the determination of $\sigma_{6}$ (the tensile stress under a million loading cycles).

It is therefore necessary to look for mechanical characteristics in the medium and long term. This paper presents compression and tensile tests results at 7, 28, 60, 90 and 360 days of age performed on cylindrical specimens (modified Proctor moulds) of silty sand stabilized with cement at rates of $2.5 ; 3.5$ and $4.5 \%$.

\section{Materials and Method}

The silty sand used in this study comes from Agbélouve, a locality located $60 \mathrm{~km}$ north of Lomé, the capital of Togo. The cement that served as a binder is supplied by CIMTOGO of Togo and is of the CPJ35 type.

The results of the identification tests on the silty sand are shown in Table 1 and Figure 1. Natural silty sand is a nonplastic fine material. The fines content of the material is $13 \%$ and its sand gleichwert is 28 . It is therefore a good material for road grading. 


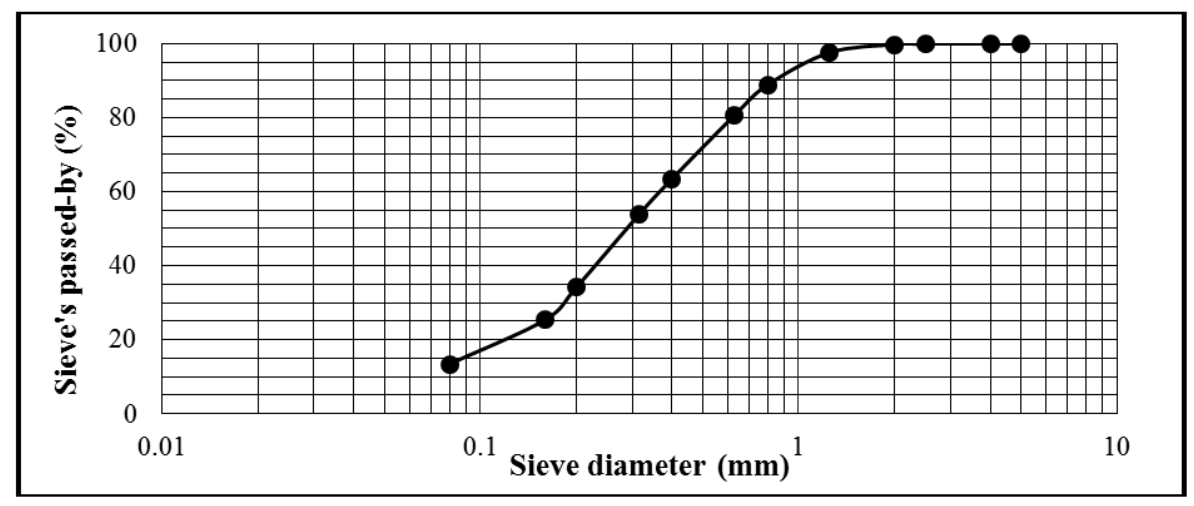

Figure 1. Studied silty sand grading curve.

Table 1. Studied silty sand characteristics.

\begin{tabular}{|c|c|c|c|c|c|c|}
\hline$\leq 80 \mu \mathrm{m}(\%)$ & $\leq 2 \mathrm{~mm}(\%)$ & $\begin{array}{l}\text { Sand Gleichwert } \\
\text { with Piston }\end{array}$ & Plasticity index & $\begin{array}{l}\text { Proctor optimum } \\
\text { density }\left(\mathrm{g} / \mathrm{cm}^{3}\right)\end{array}$ & $\begin{array}{l}\text { Proctor optimum } \\
\text { water content }(\%)\end{array}$ & $\begin{array}{l}\text { CBR at } 4 \text { days of } \\
\text { imbibition }(95 \% \text { OPM) }\end{array}$ \\
\hline 13 & 100 & 28 & not measurable & 2,00 & 5,8 & 26 \\
\hline
\end{tabular}

To achieve our objective of determining tensile and compressive strengths at different ages of silty sand stabilized at different cement rates, we proceeded to a mass variation of cement rate with respect to silty sand dry mass. The variations made are $2.5 \%, 3.5 \%$ and $4.5 \%$. On these mixtures, we determine the optimal water content of compaction of cement stabilized materials by Modified Proctor test according to standard NF P 94-093. The results of this test make it possible to make the respective test pieces at each cement rate in order to submit them to the mechanical tests (compressive and tensile strengths) at 7, 28, 60, 90 and 360 days of age. Note that the stabilized materials are kept for 7 days in a plastic film and the rest of the time in room at ambient temperature.

The simple compression tests are performed using a semiautomatic CBR press at $1.27 \mathrm{~mm} / \mathrm{min}$ speed (Figure 2). The test piece is placed between the piston and the press moving lower plate. The press piston being about $5 \mathrm{~cm}$ in diameter; a rigid disk is placed on the test piece upper face to evenly distribute the force over its entire surface. A torque ring with a capacity of $100 \mathrm{kN}$ is used to measure the compressive force by means of the Ring Force-strain calibration curve.

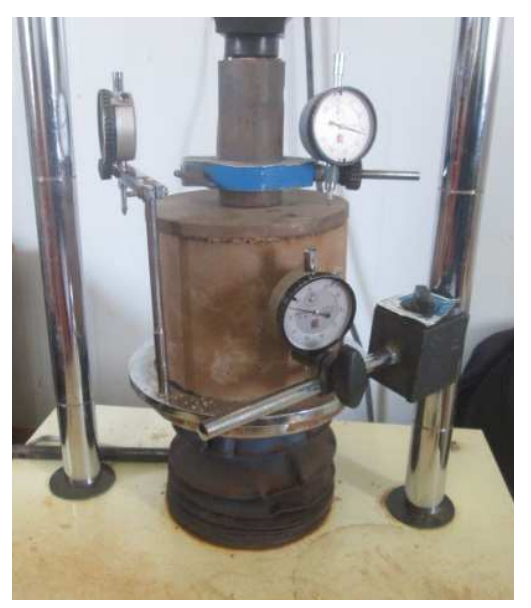

Figure 2. Device of the compression test.

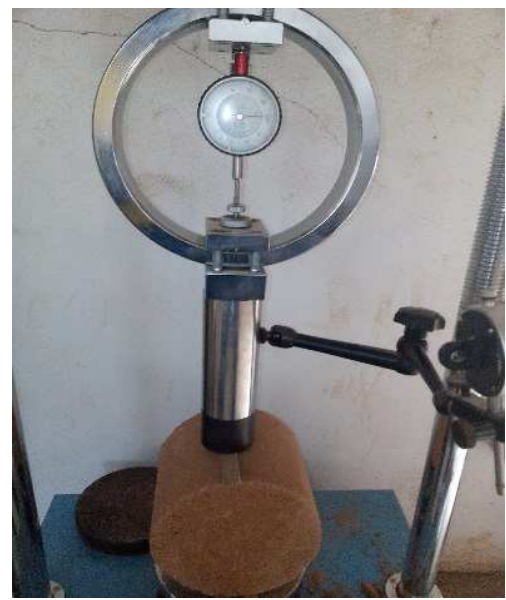

Figure 3. Device of the indirect tensile test.

The indirect tensile test (Brazilian test) is also performed with the same press as that used for compression. Splitting is done by means of a wooden box (figure 3 ). The tensile strength is given by:

$$
\mathrm{R}_{\mathrm{t}}=0,8 \frac{2 \times \mathrm{F}_{\mathrm{rupt}}}{\pi \cdot h \cdot \mathrm{d}}
$$

where:

$F_{\text {rupt }}:$ load at sample break,

h: sample height,

$d$ : sample diameter

\section{Results and Discussion}

Table 2 presents the results of Modified Proctor tests performed on stabilized silty sand. There is a slight increase in water content and optimum density depending on cement rate. Indeed, Proctor optimum density increases with cement rate of $2.05 \mathrm{~g} / \mathrm{cm}^{3}$ for $2.5 \%$ cement, at $2.08 \mathrm{~g} / \mathrm{cm}^{3}$ for 3.5 and $4.5 \%$ cement, as well as in optimal water content (Table 2). It is at these respective water contents that the specimens are manufactured for the mechanical tests. 
Table 2. Results of the Proctor test on silty sand stabilized at different cement rates.

\begin{tabular}{lll}
\hline Cement rate (\%) & Proctor optimum density $\left(\mathbf{g} / \mathbf{c m}^{\mathbf{3}}\right)$ & Proctor optimum water content $(\%)$ \\
\hline 2.5 & 2.05 & 5.9 \\
3.5 & 2.08 & 6.0 \\
4.5 & 2.08 & 6.1 \\
\hline
\end{tabular}

The results of mechanical tests (average compressive and tensile strengths) are presented in Tables 3 and 4 as well as the standard deviations obtained. Each value is the average of three (03) identical specimens results.

Table 3. Compression tests results as a function of cement rate and age.

\begin{tabular}{lllll}
\hline \multirow{2}{*}{ Cement rate } & \multicolumn{4}{l}{ Compression strength \pm standard deviation (MPa) } \\
\cline { 2 - 5 } & 7 days & $\mathbf{2 8}$ days & $\mathbf{6 0}$ days & $\mathbf{9 0}$ days \\
\hline $2.5 \%$ & $0.98 \pm 0.04$ & $1.81 \pm 0.02$ & $2.61 \pm 0.07$ & $3.66 \pm 0.06$ \\
$3.5 \%$ & $2.08 \pm 0.05$ & $4.10 \pm 0.03$ & $5.61 \pm 0.09$ & $7.41 \pm 0.07$ \\
$4.5 \%$ & $2.72 \pm 0.06$ & $5.09 \pm 0.17$ & $6.17 \pm 0.09$ & $7.37 \pm 0.20$ \\
\hline
\end{tabular}

Table 4. Tensile tests results as a function of cement rate and age.

\begin{tabular}{llllll}
\hline \multirow{2}{*}{ Cement rate } & \multicolumn{5}{l}{ Tensile strength \pm standard deviation (MPa) } \\
\cline { 2 - 6 } & $\mathbf{7}$ days & $\mathbf{2 8}$ days & $\mathbf{6 0}$ days & $\mathbf{9 0 \text { days }}$ & $\mathbf{3 6 0}$ days \\
\hline $2.5 \%$ & $0.10 \pm 0.00$ & $0.17 \pm 0.00$ & $0.26 \pm 0.01$ & $0.37 \pm 0.02$ & $0.41 \pm 0.01$ \\
$3.5 \%$ & $0.19 \pm 0.02$ & $0.36 \pm 0.00$ & $0.53 \pm 0.00$ & $0.68 \pm 0.01$ & $0.75 \pm 0.02$ \\
$4.5 \%$ & $0.27 \pm 0.00$ & $0.44 \pm 0.02$ & $0.58 \pm 0.01$ & $0.74 \pm 0.03$ & $0.82 \pm 0.01$ \\
\hline
\end{tabular}

Variation coefficients of the different values are between 0 and $5 \%$ for compression tests and between 0 and 10\% for tensile tests. This shows a slight dispersion between the results obtained.

From Tables 3 and 4 results, we draw Figure 4 curves which show, for a given age, the resistances evolution as a cement rate function. These curves are all increasing, which reflects an increase in resistance with cement rate. In compression and according to the age considered, specimens stabilized at $3.5 \%$ increase in strength from 76 to $127 \%$ compared to the specimens stabilized at $2.5 \%$ while for specimens stabilized at $4.5 \%$, we only note a resistance gain of the order of 6 to $30 \%$ compared to specimens stabilized at $3.5 \%$.

This tendency of resistance difference according to the rate

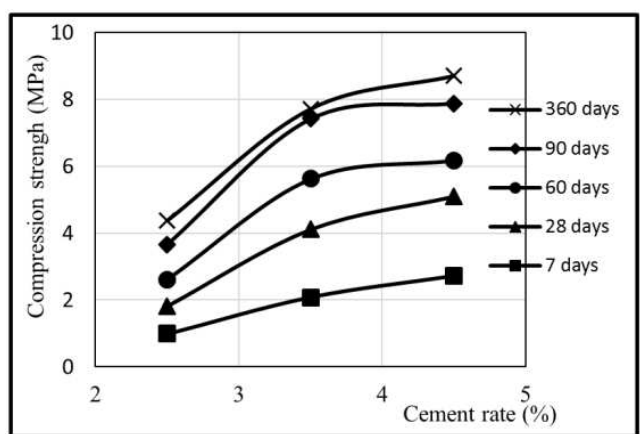

of cement is also observed in traction where the specimens stabilized at $3.5 \%$ increase in strength by 83 to $110 \%$ compared to the specimens stabilized at $2.5 \%$ while for specimens stabilized at $4.5 \%$, only a resistance gain of the order of 8 to $44 \%$ is noted compared to the specimens stabilized at $3.5 \%$.

These results show us that at the same age, despite the same rate of variation of cement $(1 \%)$, the resistance gain between the specimens stabilized at 3.5\% compared to the specimens stabilized at $2.5 \%$ is significantly higher than that the resistance gain noted between the specimens stabilized at $4.5 \%$ compared to those stabilized at $3.5 \%$. It should be noted that dry densities of specimens stabilized at $3.5 \%$ and $4.5 \%$ are almost equal to and greater than that of specimens stabilized at $2.5 \%$.

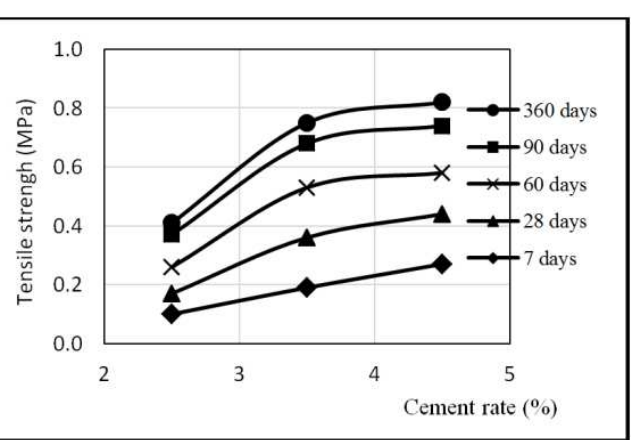

Figure 4. Compressive and tensile strengths evolution as a cement rate function.

From Tables 3 and 4, we also obtain Figure 5 curves which reflect resistances evolution as an age function for a given cement rate. The shape of mechanical characteristics evolution curves as an age function depends little on cement rate. These results show that compressive and tensile strengths grow rapidly at a young age.

Indeed, between 7 and 28 days and according to the dosage $(2.5,3.5$ and $4.5 \%)$ this growth is of the order of 85 to
$97 \%$ for compressive strengths and of 70 to $90 \%$ for tensile strengths. Growth rate decreases beyond 28 days:

for compressive strengths, it is 21 to $44 \%$ between 28 and 60 days, 27 to $40 \%$ between 60 and 90 days and 4 à $19 \%$ between 90 and 360 days;

and for tensile strengths, it is 32 to $47 \%$ between 28 and 60 days, 28 to $44 \%$ between 60 and 90 days and 10 à $11 \%$ between 90 and 360 days. 

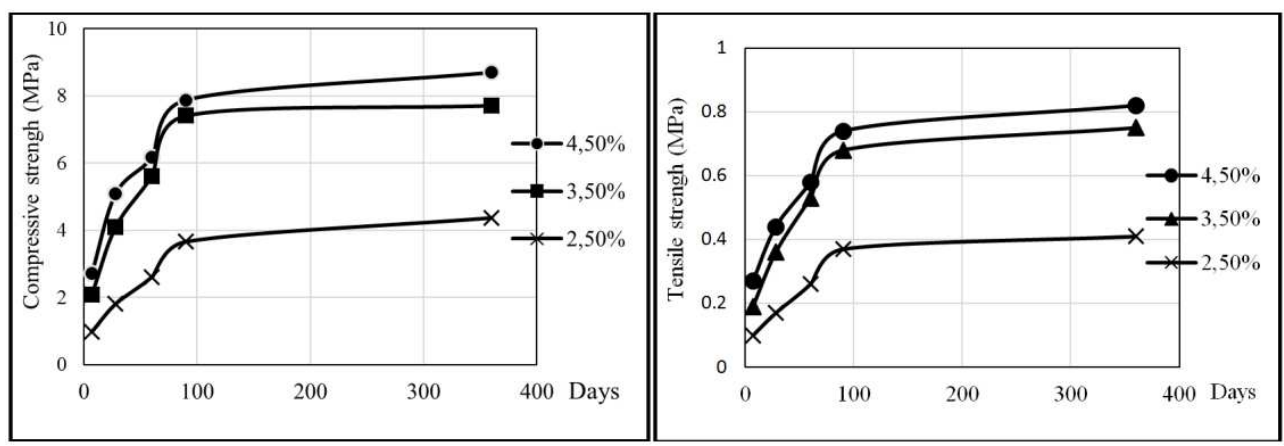

Figure 5. Compressive and tensile strengths evolution as an age function.

Table 5 gives the values of the ratio between compressive and tensile strengths. This ratio varies between 9.80 and 11.57. These values confirm the ratio of 10 generally supposed between compressive and tensile strength for cement-treated materials including concrete.

Table 5. Ratio between compressive and tensile strength.

\begin{tabular}{llll}
\hline \multirow{2}{*}{ Ratio } & \multicolumn{3}{l}{ Cement rate } \\
\cline { 2 - 4 } & $\mathbf{2 . 5 \%}$ & $\mathbf{3 . 5 \%}$ & $\mathbf{4 . 5 \%}$ \\
\hline $\mathrm{R}_{\mathrm{c} 7} / \mathrm{R}_{\mathrm{t} 7}$ & 9.80 & 10.95 & 10.00 \\
$\mathrm{R}_{\mathrm{c} 28} / \mathrm{R}_{\mathrm{t} 28}$ & 10.60 & 11.39 & 11.57 \\
$\mathrm{R}_{\mathrm{c} 60} / \mathrm{R}_{\mathrm{t} 60}$ & 10.03 & 10.58 & 10.64 \\
$\mathrm{R}_{\mathrm{c} 90} / \mathrm{R}_{\mathrm{t} 90}$ & 9.89 & 10.90 & 10.65 \\
$\mathrm{R}_{\mathrm{c} 360} / \mathrm{R}_{\mathrm{t} 360}$ & 10.66 & 10.28 & 10.61 \\
\hline
\end{tabular}

In Table 6, we present the ratios between tensile strength at the different days and that at 360 days.

Table 6. Ratios between tensile strength at the different days and that at 360 days.

\begin{tabular}{llllll}
\hline \multirow{2}{*}{ Cement rate } & \multicolumn{4}{l}{ Ratio $\mathbf{R}_{\mathbf{t}} / \mathbf{R}_{\mathbf{t} 360}$} \\
\cline { 2 - 6 } & $\mathbf{7}$ days & $\mathbf{2 8}$ days & $\mathbf{6 0}$ days & $\mathbf{9 0}$ days & $\mathbf{3 6 0}$ days \\
\hline $2.50 \%$ & 0.24 & 0.41 & 0.63 & 0.90 & 1 \\
$3.50 \%$ & 0.25 & 0.48 & 0.71 & 0.91 & 1 \\
$4.50 \%$ & 0.33 & 0.54 & 0.71 & 0.90 & 1 \\
\hline
\end{tabular}

We note that the ratio between tensile strength at 7 days and that at 360 days is of the order of 0.30 and therefore different from the empirical value 0.60 [10] often used when it is not possible to make 360-day trials. This difference may be related to cement nature (class).

For road structures design, it is necessary to determine the fatigue resistance under one million loading cycles $\left(\sigma_{6}\right)$ from the fatigue tests and to deduce the design fatigue resistance value. In the absence of fatigue tests, the SETRA pavement design and dimensioning guide [10] proposes an empirical relationship between the 360-day tensile strength $\left(\mathrm{R}_{\mathrm{t} 360}\right)$ and the fatigue resistance under one million loading cycles $\left(\sigma_{6}\right)$ for cement stabilized sands:

$$
\frac{\sigma_{6}}{\mathrm{R}_{\mathrm{t} 360}}=0,93
$$

From the fatigue resistance under one million loading cycles, the material design fatigue resistance $\left(\sigma_{6}{ }_{6}\right)$ is determined. This resistance is: $[9 ; 12]$

$$
\sigma_{6}^{\prime}=0,75\left(\frac{\sigma_{6}}{R_{\mathrm{t} 360}}\right) \mathrm{R}_{\mathrm{t} 360}
$$

From equations (2) and (3), we obtain the values of $\sigma_{6}$ and the material design fatigue resistance (Table 7).

Table 7. Fatigue resistance and design fatigue resistance.

\begin{tabular}{llll}
\hline Cement rate (\%) & Tensile strength at 360 days $\left(\mathbf{R}_{\mathbf{3 3 6 0}}\right)$ in $\mathbf{M P a}$ & Fatigue resistance $\left(\boldsymbol{\sigma}_{\mathbf{6}}\right)$ in $\mathbf{M P a}$ & Design fatigue resistance $\left.\left(\boldsymbol{\sigma}_{\mathbf{6}}\right)\right)$ in $\mathbf{M P a}$ \\
\hline 2.5 & 0.41 & 0.38 & 0.29 \\
3.5 & 0.75 & 0.70 & 0.53 \\
4.5 & 0.82 & 0.76 & 0.57 \\
\hline
\end{tabular}

\section{Conclusion}

The study of the Agbelouve silty sand stabilized with cement presented in this article consisted of the determination of its compressive and tensile strength at different ages up to 360 days. The objective is to check correlations between breaking strengths at different ages with current correlations but also to determine the fatigue resistance to be used in the design of roadway by the rational method, in particular via the software Alize. Compressive and tensile strengths were determined on samples made in CBR moulds and 0.84 of slenderness. The design fatigue resistance was obtained by the correlation between the tensile strength at 360 days and fatigue resistance under one million loading cycles $\left(\sigma_{6}\right)$ proposed in the dimensioning guide [10]. Investigations will have to be carried out on the same category materials of the region and different categories including lateritic for a probable generalization.

\section{References}

[1] NF P 18-598, Granulate-Sand gleichwert. Association Française de Normalisation, October 1991.

[2] NF P 94-056, Soil: investigation and testing-granulometric analysis-dry sieving method after washing. Association Française de Normalisation, March 1996. 
[3] NF P 94-078, Soils: Investigation and tests-CBR after immersion-Immediate CBR-Immediate bearing ratioMeasurement on sample compacted in CBR mould. Association Française de Normalisation, May 1997.

[4] NF P 94-093 Soils: Investigation and testing-Determination of the compaction characteristics of a soil-Standard Proctor testModified Proctor test. Association Française de Normalisation, October 2014.

[5] NF P 98-113. Roadbeds: Sands treated with hydraulic and puzzolanic binders. Definition-Composition-Classification. Association Française de Normalisation, November 1994.

[6] NF P 98-114-2. Roadbeds Methodology of a laboratory study of materials treated with hydraulic binders. Part 2: Sands treated with hydraulic binders. Association Française de Normalisation, May 2009.

[7] NF P 98-114-3. Roadbeds Methodology of a laboratory study of materials treated with hydraulic binders. Part 3: Soils treated with hydraulic binders possibly associated with lime. Association Française de Normalisation, May 2009.

[8] NF P98-232-3. Determining the mechanical characteristics of materials treated with hydraulic binders. Indirect tensile strength test on sands and fine soils. Association Française de Normalisation, November 1997.

[9] NF EN 13286-53-Unbound and hydraulically bound mixtures. Part 53: Methods for the manufacture of test specimens of hydraulically bound mixtures using axial compression. Association Française de Normalisation, May 2005.

[10] LCPC - SETRA, Design and dimensioning of road structures, technical guide, Conception et dimensionnement des structures de chaussée, guide technique, 1994.

[11] N. E. ABRIAK, D. WANG, R. ZENTAR1, Estimation of the long-term mechanical properties of Dunkerque sediments treated with lime or cement, Estimation des propriétés mécaniques à long terme des sédiments de Dunkerque traités à la chaux ou au ciment. Revue française de géotechnique, No: 142, 1er trimestre 2013, p 39-47.

[12] Scordia P. Y., Lafhaj Z., Skoczylas F, Mongeois F., Characterization and valorization in road technique of polluted and treated river sediments, Caractérisation et valorisation en technique routière de sédiments fluviaux pollués et traités. Revue européenne de génie civil, vol. 12, No: 9-10, 2008, p. 1087-1104.

[13] Joseph Abdo, Jean-Pierre Serfass, Earthworks and roadway courses: Treatment of soil with hydraulic binders, Terrassements et assises de chaussées; Traitement des sols aux liants hydrauliques, Collection Technique CIMBETON, Tome 70, november 2009.

[14] Nor-Edine Abriak, Mahfoud Benzerzour, Mouhamadou Amar, Abdeljalil Zri, Study of the potential of raw sediments and sediments treated with lime or cement for use in a foundation layer and the base layer of a roadway. World Academy of Science, Engineering and Technology International Journal of Civil and Environmental Engineering Vol: 10, No: 12, 2016, p 1680-1689.

[15] Md. Mahmud Hasan Mamun, Md. Firoz Mahmood Ovi, Farhana Akhter, Saurav Barua, Mohiuddin Ahmed, Thahomina Jahan Nipa. Improvement of Sub Base Soil Using Sand-Cement Stabilization. American Journal of Civil Engineering. Vol. 4, No. 5, 2016, pp. 241-246. Doi: 10.11648/j.ajce.20160405.15.

[16] Reza Jamshidi Chenari, Behzad Fatahi, Ali Ghorbani and Mohsen Nasiri Alamoti. Evaluation of strength properties of cement stabilized sand mixed with EPS beads and fly ash. Geomechanics and Engineering Volume 14, Number 6, April 30 2018, p 533-544. Doi: https://doi.org/10.12989/gae.2018.14.6.533.

[17] Molaabasi Hossein, Shooshpasha Issa. Evaluation of zeolite effect on strength of babolsar sand stabilized with cement using unconfined compression test. Modares Civil Engineering Journal. November 2016, Volume 16, Number 5 (supplement); p 203-213.

[18] Emmanuel Mengue, Hussein Mroueh, Laurent Lancelot, Robert Medjo Eko. Dimensioning of a foundation course based on a lateritic soil treated with cement at different dosages. Dimensionnement d'une assise de chaussée à base d'un sol latéritique traité au ciment à différents dosages. Rencontres Universitaires de Génie Civil, May 2015, Bayonne, France. hal-01167731.

[19] Bachir Melbouci. Comparative study of marl soil treatment with lime and cement in pavement layers. Etude comparative du traitement du sol marneux à la chaux et au ciment dans les couches de forme des chaussées. Communication Science \& technology vol 18. January 2017, p 79-98.

[20] V. Ramesh Babu, K. Niveditha, B. Ramesh Babu. Stabilization of black cotton soil with sand and cement as a subgrade pavement. International Journal of Civil Engineering and Technology. Volume 7, Issue 2, March-April 2016, p. 341-351. 